\title{
Vooruit of achteruit kijken bij toelating tot de postdoctorale opleidingen?
}

Marc Wouters

Ik herinner me nog goed mijn verbazing toen ik in de jaren negentig binnen Ernst \& Young samenwerkte met een Engelse collega die accountant was. Na verloop van tijd begreep ik namelijk dat Jonathan een bachelordiploma had in diergeneeskunde. Daarna was hij in accountancy en financieel management verder gegaan. Dat deden er wel meer in het Engelse systeem. In Nederland, zo hoorde ik altijd van collega's, duurde de postdoctorale opleiding tot RA heel lang en vereiste deze een hele specifieke afstudeerrichting van bedrijfseconomie op de universiteit. De postdoctorale RC-opleidingen begonnen toen net op te komen, en die stelden ook specifieke eisen aan de universitaire vooropleiding. Een opmerkelijk verschil met Engeland.

In deze column wil ik pleiten voor een andere benadering van de toelating van studenten tot de RA- en RC-opleidingen. Mijn advies: flexibeler zijn met betrekking tot zijinstromers in het vakgebied, maar wel vasthouden aan het hoge niveau. Onderschat niet wat gemotiveerde en slimme mensen met een andere vooropleiding snel kunnen oppakken.

Vele opleidingswegen leiden naar een financiële functie. Ik bedoel hier bijvoorbeeld controller of financieel directeur en niet accountant (in de Nederlandse betekenis van het woord, dus in het Engels eerder 'auditor' dan 'accountant'). Veel mensen met een financiële functie zijn RA. Onlangs nog bleek uit onderzoek van Yacht dat RA's buiten de accountantskantoren onverminderd gewild blijven, bijvoorbeeld bij bedrijven, overheden of banken. Veelal hebben zij een aantal jaren werkervaring bij een accountantskantoor achter de rug en maken ze de overstap naar een bedrijfseconomische functie. Ze willen professioneel breder bezig zijn of de handen jeuken om zaken te doen in plaats van te controleren. Zij zullen ongetwijfeld in hun werk gebruikmaken van specifieke kennis van 'auditing', maar meer nog van hun bredere financiële kennis.

Vooral 'vroeger' was registeraccountant bij het NIVRA een zware maar hoogwaardige opleiding voor mensen die na de middelbare school meteen aan het werk moesten, maar eigenlijk wilden studeren (net als bijvoorbeeld in die tijd de opleidingen voor leraar in het middelbaar onderwijs). Zo is mijn vader in de jaren vijftig na de hbs in administratieve functies begonnen en is hij via diverse opleidingen naast een dagtaak RA geworden. Er waren toen overigens ook postdoctorale RA-opleidingen aan de universiteiten. $\mathrm{Nu}$ is het weer anders in de vorm van postdoctorale opleidingen die in combinatie met werkervaring tot het RA-diploma leiden.

Sinds de jaren negentig kennen we in Nederland de postdoctorale RC-opleidingen. Er was behoefte aan een opleiding die qua niveau vergelijkbaar is met de RA-opleiding, maar die al meteen is gericht op bedrijfseconomische functies waar veel RA's sowieso later liever in terecht komen.

Daarnaast zien we dat mensen met een andere universitaire opleiding dan bedrijfseconomie op een financiële functie terecht komen, zoals ingenieurs of bestuurskundigen. De 'omscholing' tot financieel professional gebeurt op verschillende manieren, zoals via een post-hbo-opleiding, een controllersopleiding die door een groot bedrijf zelf is ingesteld, of door te blijven bijleren in de praktijk en met kortere cursussen. De RC-opleidingen zijn vaak behoorlijk afhoudend.

Maakt het nou wat uit welke opleidingsweg gevolgd is? De praktijk laat zien dat het er niet zoveel toe doet. Daarom lijkt het me verstandig als er ruimhartiger wordt omgegaan met de toelating tot vervolgopleidingen. Kijk minder 
naar de inhoud van de vooropleiding van studenten, maar toets heel zwaar op het niveau en de motivatie. Kijk vooruit in plaats van achteruit: hoe groot achten we de kans dat iemand de opleiding met succes kan doorlopen, in plaats van: past iemand voor aanvang in het keurslijf?

Neem als voorbeeld de RC-opleiding. Deze zou naar mijn mening mensen met een degelijke opleiding en relevante werkervaring vaker en met minder deficiënties moeten toelaten. $\mathrm{Nu}$ worden mensen regelmatig alleen toegelaten als ze eerst vooraf een groot pakket deficiënties wegwerken. Het uitgangspunt is kennelijk: de studenten moeten eerst worden gehomogeniseerd en voor aanvang dezelfde kennis hebben. Maar waarom eigenlijk? Het uitgangspunt zou naar mijn mening moeten zijn: kan iemand met zijn/haar voorkennis, ervaring, intelligentie, motivatie en studievaardigheden het programma succesvol afronden? Dat hoeft niet voor iedereen dezelfde voorkennis te zijn. Natuurlijk kan iemand het bij bepaalde vakken extra moeilijk hebben (en wat gemakkelijker bij andere vakken). Maar geef studenten liever extra studiemateriaal waarmee ze voorkennis kunnen bijspijkeren tegelijk met het betreffende vak uit de RC-opleiding. Trouwens, in de praktijk gebeurt dat soms ook: studenten doen soms de deficiënties samen met een regulier vak, ondanks boze brieven van de opleiding dat dat zo niet mag. Maar wat is het probleem?

Ik ken de RA-opleidingen minder goed, maar daarvoor geldt ongeveer hetzelfde. Registeraccountant is een moeilijk vak, maar het is geen rocket science. Ik zou niet weten waarom intelligente en gemotiveerde mensen met bijvoorbeeld een opleiding econometrie, (technische) bedrijfskunde of wiskunde de RA-opleiding niet succesvol zouden kunnen afronden. Geef ondersteuning en ruimte tijdens het programma. Ook in de beroepsgroep wordt hierover weleens gediscussieerd, maar de centrale regels blijven star.

Overigens speelt iets vergelijkbaars in de tegenwoordige universitaire opleidingen, die zijn gesplitst in een bachelor- en masteropleiding. Hoe specifiek zijn de inhoudelijke eisen die je stelt aan de bacheloropleiding bij toela- ting tot een bepaalde masteropleiding? Sommigen willen eigenlijk alleen studenten opleiden uit de eigen of vrijwel dezelfde bacheloropleiding, en anderen komen er niet in of moeten eerst allerlei deficiënties wegwerken. Maar ook in deze situatie kun je meer vooruit kijken in plaats van achteruit: hoe groot achten we de kans dat een bepaalde student, ook al is deze wat anders dan de 'eigen' studenten, toch de opleiding met succes kan doorlopen? Mijn ervaringen zijn positief. Een slimme en gemotiveerde student met een ongeveer aansluitende bacheloropleiding is succesvoller in de masteropleiding dan een matige student met de 'perfecte' vooropleiding.

Het eerdergenoemde onderzoek van Yacht is optimistisch, want er is een structureel tekort op de arbeidsmarkt aan echte deskundigen. 'Dat blijft in de toekomst zo. Financiële thema's als kostenbeheersing, risicomanagement, werkkapitaal, overnames en integraties staan hoog op de agenda van organisaties. Op dit moment is er wat meer evenwicht tussen vraag en aanbod, maar je ziet aan de instroomcijfers op de opleidingen dat het tekort in de toekomst weer zal oplopen', volgens Yacht. Naar mijn idee onderstreept dit het belang van hoogwaardige opleidingen en de waardering van vakkennis. Dit is prima te combineren met een bredere en betere instroom. Dat is geen tegenstelling!

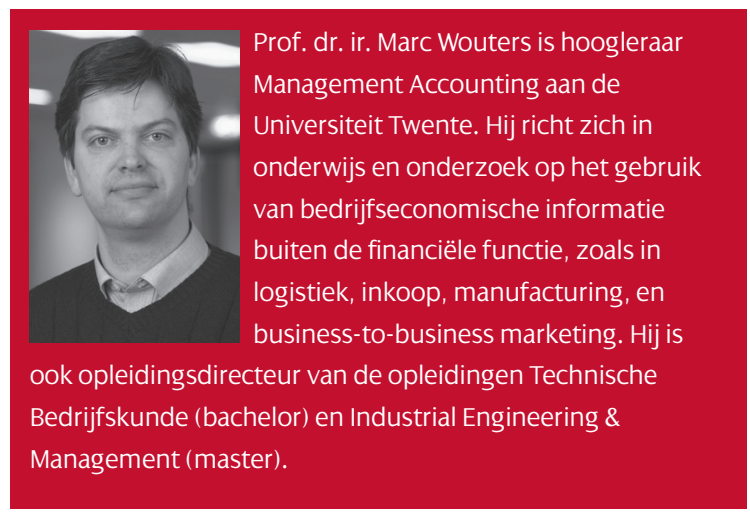

